Marquette University

e-Publications@Marquette

$1-1-2006$

\title{
Government and Corporate Initiatives for Indian Women in IT
}

Monica Adya

Marquette University, monica.adya@marquette.edu

Published version. "Government and Corporate Initiatives for Indian Women in IT" in Encyclopedia of Gender and Information Technology. Eds. Eileen M. Trauth. Hershey, PA: IGI Global, 2006: 739-744. DOI. (c) 2006 IGI Global. Used with permission. 


\title{
Government and Corporate Initiatives for Indian Women in IT
}

\author{
Monica Adya \\ Marquette University, USA
}

\section{INTRODUCTION}

Education of women severely lags behind that of men in many developing nations. Fewer girls go to school, tend to drop out earlier than boys, do not receive the same level of education as their male counterparts, and often choose careers that are female predominant (Kelly, 1987). Without exception, India is quite representative of these genderbiased phenomena in education. However, the recent explosion of offshore outsourcing market in India has created a new recognition regarding the role of women in technological careers. The Indian IT sector has seen a trend contrary to what most western nations are experiencing-predominance of women in IT, particularly in IT-enabled services (ITES).

India has acknowledged that extensive and intensive use of information and communications technologies (ICT) alone can help the nation develop its neglected human resources, emerge as a knowledge-based society, and participate competitively in the global trade and services. Consequently, the development of ICT has become a national issue with strong impetus from the union government in New Delhi (Choudhary, 1999). Explicit in this initiative is the recognition that to progress as an information society, women must be empowered as key players the IT sector. In parallel, two other trends have focused attention on women in the information society-a nationwide movement for women's rights spearheaded by many non-government organizations (NGOs) and an increased awareness of corporate social responsibility. Consequently, over the last decade, there has been an increased emphasis on education and reskilling India's female workforce. While many government efforts are targeted toward the overall upliftment of women, many grassroots level initiatives led by NGO's and corporations emphasize technological training,
This article highlights how the intertwining of grassroots and policy level efforts can increase the pace at which a nation's female workforce can be reskilled and prepared for a technological world. The article also addresses concerns about such rapid development and potentially challenging outcomes while making recommendations for improvement.

\section{BACKGROUND}

In many contexts, India is a representation of paradoxes. Over $44 \%$ of India's population is below the poverty line, its per capita income is under $\$ 100$, and adult literacy rate is about $44.3 \%$. Yet, the Indian education system churns out young minds that have excellent training in math, science, and technology (MST). While only $25 \%$ of India's urban population and $1.5 \%$ of its rural population has access to telephones, India boasts of one of the fastest growing software industries in the world.

The role of women in the Indian society remains similarly paradoxical. India was one of the first countries to give voting rights to women subsequent to emancipation from British rule in 1947 (UNESCO, 2002). The country was led by a woman prime minister for several decades, a rarity on a global scale. Religious scriptures lay particular emphasis on the power of the woman to enable a progressive society. However, while the Indian constitution grants many legal rights to women, the socio-economic status of women still seriously lags behind that of men.

There has been no dearth of government initiatives in India in the past to promote equalization of gender roles. Yet some of the most meaningful schemes have emerged only in recent years for several reasons: the IT sector has experienced rapid growth due to global sourcing, monetary compensa- 
tions for IT related positions have increased dramatically, and many NGOs, women's organizations, and corporations have become more radically involved in female participation to leverage these trends. The next few sections examine the role of these entities in the advancement of women in the IT sector.

\section{MAIN THRUST}

The function of government in India's workforce development reflects a trend that has been observed in many western nations where the government has gradually withdrawn from the direct delivery of many programs and has increasingly relied on nonprofit organizations to take on this role (Zappala, 2000). NGO's and corporations have stepped in to implement and deliver government policies for improvement of education and working conditions.

\section{Government: An Overall Emphasis on Girls and Women}

Governments in many developing countries, including India, have been instrumental in providing funding for IT education and training to encourage everyone, not just women, to become technically sophisticated. Women have, however, seized these opportunities willingly because IT work presents an opportunity for women to compete with men cerebrally - rather than physically (Sneddon, 2004). One such initiative in recent years has been making education pervasive in all households. While not an IT initiative, the most common educational policies and goals are not intended to help one group of users more than any others (Klein, 1987). In year 2000, the government initiated a $\$ 250$ million national program with the objective of enrolling all children between 6 14 years of age in the educational system by 2010 (UNESCO, 2004). Subsets of this program, National Program for the Education of Girls at the Elementary Level (NPEGEL) and Kasturba Gandhi Swantantra Vidyalay (KGSV) focus on bringing girls into the education stream. This program is aimed at developing model elementary schools in 21 states with an emphasis on providing benefits for underprivileged and under represented girls in education. This is a start to overcoming one of the most serious barriers to representation of women in the workforce in India - increased and improved education for girls. As a part of these umbrella reforms in the Indian educational infrastructure, the government has established proactive policies for girls' enrolment in science, engineering, and technology (SET) courses. Computer literacy excellence awards for schools that demonstrate promotion of technological education have been initiated to encourage schools and colleges to examine and improve their IT curricula.

The residual effects of widespread women's movements are evident in the declaration of Year 2001 as the "Women Empowerment Year." While the general objective of this initiative was to provide self-awareness and generate an environment conducive to development of self-confidence and assertiveness among women, a significant portion of this initiative was devoted to women in technology. Specifically, some plans related to:

- Establishment of technology parks

- National assessment of technology drudgery reduction, tools and implements income generation for women

- A traveling exhibition of women in MST

The establishment of the Ministry of Communications and Information Technology (MIT) has provided a significant impetus to the development of India's IT workforce. The multitude of projects undertaken by this ministry includes:

- Establishment of a task force with the intent of setting up a long-term strategy for development of a strong IT workforce

- Provision of employment oriented training for educated youth to meet the shortage of trained IT professionals

- Development of curricula in cyber security and IT systems management

- Setting up ERNET, a network for academic and research institutions

The ministry has also instituted the "IT Super Power Group" to promote improvement of IT workforce whose immediate concern is to address issues regarding women in technology and technology development in rural areas. While MIT has been 
actively involved in the development of broad policy initiatives, many of these are filtering down to women through NGO's and corporations.

\section{Government Support for Higher Education and Training Initiatives in Technology}

Recognizing that implementation of many programs must occur from the grassroots, specifically educational institutions and other non-academic training institutes, the government of India began providing more support to private institutions and colleges that impart technology training. The recent establishment of the Department of Education Accreditation of Computer Courses (DOEACC) has enabled accreditation of educational institutions on their technology course offerings (DDSI, 2002). This division of the MIT provides accreditation at four levels-from diploma and certification to MS programs. The government also has plans for Indian Institutes of Technology Management (IITM) modeled after the prestigious Indian Institutes of Technology (IIT) that have produced talented workforce in MST for decades. IITM is expected to continue this effort with focused attention on IT workforce development.

\section{Improving Working Conditions for Women in Technology}

Outsourcing from the western countries has posed a unique demand on the Indian workforce. IT service providers must now work in 24-hour shifts to complement working hours of their western clients. Women desiring to leverage growth in the IT sector must adapt to these new requirements. Since corporations were not under mandate to provide conducive working environments for women, these long and awkward hours of IT work were discouraging.

In recent years, however, working conditions for women in IT have received much attention from state and federal governments. Of particular interest is the State of Karnataka, home of India's Silicon ValleyBangalore. Karnataka has instituted policies that require at least five women to be employed during night shift in an IT company, free transportation to and from home, adequate number of women security guards on the premises, privacy for women employ- ees, and provision of day-care facilities for children under the age of six. Similar initiatives have been instituted by the city of Chandigarh, which requires sufficient security and transportation for all women between 18-21 working on night shift in ITES industries. While such policies are not pervasive in India yet, the government's role in rapid policy creation and of corporations in policy implementation has been encouraging.

\section{Women IT Entrepreneurs}

With $65 \%$ representation, ITES represents a successful sector for women in India. Much of this success can be attributed to involvement of women from lower income strata in setting up IT entrepreneurships. Several government initiatives have been focusing on promoting technology development in rural India with particular emphasis on promoting women IT entrepreneurs. Mother Teresa Women's University has initiated new courses for promoting high-tech professional entrepreneurship among women. These courses are offered in conjunction with the University Grants Commission (UGC), the only educational grant giving institution in India. The government has also empowered certain banks to provide liberal loans conditions such as reduced interest rate and relaxed margins for women.

\section{Non-Government Organizations}

In an attempt to harness the forces of rural and lowincome populations in India, several programs train and educate underprivileged women in IT. One such example is World Bank's SITA (Studies in Information Technology Applications) program for low income and socially underprivileged women, which is part of a larger initiative for gender empowerment. About 507 women from families with incomes less than $\$ 60$ were given free intensive hands-on computer training based on real life exercises using MS Office 2000. Some trainees were attached to a potential employer. Trainees were required to offer part-time services as an assistant Trainer, after completing her course in order to provide confidence required in the workplace. MitraMandal, a co-operative enterprise has fur- 
thered SITA by continuing to train women from lowincome families (Sane, 2001)

India's National Institute of Information Technology (NIIT) was formed in 1981 with the intention of providing certificate training in information technology. Recognizing the alarming trend of low female representation in their own curriculum as well as in the U.S., NIIT's recent ventures provide basic technology education for women and children. In particular, two initiatives have particularly been focused in this direction-Hole in the Wall and Swift Jyoti. The former program provides training to children in technology while developing their ability to self-train in technology. The Swift Jyoti program was designed with the intention of "bringing 50,000 women and computers together." This low cost (\$15), three-week program provides functional computer literacy for women in four languages. NIIT recently provided free training to 5000 teachers and principals. Another program initiated by the organization is BOOT IT, a television-based distancelearning project, to bring computer education free to the homes of millions of Indians. In an attempt to bring awareness to these issues, NIIT has launched programs such as World Computer Literacy Day and International Women's Month (NASSCOM, 2003).

\section{Industrial Partnerships}

Many corporations are beginning to recognize, as a part of their social responsibilities, the need to provide technical education to underprivileged girls. Examples of such organizations are vMoksha and Xansa. vMoksha has partnered with Navjaeevna, a home for underprivileged girls, to provide basic computer knowledge and awareness of the relevance of computer education. To initiate the program, vMoksha donated computers and employed a teacher to give the girls a basic IT education.

Corporations such as Xansa have recognized through their IT initiatives that corporate social responsibilities must extend beyond the provision of IT education. Xansa, a UK based IT outsourcing firm, has consciously been involved in the development of IT workforce through support for underprivileged sections of the Indian population. It initially adopted schools and villages with the intention of providing basic computer education. However, it soon recognized that that lack of basic amenities such as water, clean and hygienic environments, and education were a greater bane for these schools and villages and has subsequently partnered with other social institutions such as Pratham to better provide these amenities to schools and villages.

Realizing the important role of technology in adult education and job training, IBM has set up the Gandhi Institute of Computer and Information Technology, in partnership with the Bharatiya Vidya Bhawan. This institute provides free computer education to students from the economically weaker sections of society. IBM has donated PCs and other equipment to open a computer center for imparting training to the visually impaired students of the Victoria Memorial School for the Blind in Mumbai. IBM has also extended its computer camps for middle-school girls, EXITE (Exploring Interest in Technology and Engineering), to India. In this program, girls receive hands-on experience and support, while learning how to break down and rebuild computers, construct web sites, build and program a Lego robot, and develop presentations among other tasks. The goal is to encourage girls' interest in MST and provide an in-depth look at career opportunities in the field of technology (IBM, 2005).

India's leading outsourcing provider, Tata Consultancy Services (TCS) has developed computerized programs to address the adult literacy problem in India. The company has undertaken adult education projects in many states. Microsoft has committed to the provision of academic software worth \$I million for five years to children studying in various schools in the country with the intent of providing basic software training in MS Office, Visual Basic, and other common software packages. These applications are being provided to public schools that typically do not have funds to obtain such resources. With a strong belief that India's educational system need to be strengthened, Polaris has set up "Ullas" trust, which gives monetary aid to students who cannot afford education on their own. It is also providing them free computer training at its office premises. Many of these corporations such as Infosys, TCS, and Polaris are also providing volunteer time and funds for promotion of general welfare of women and children and have subsumed technological training under this larger initiative. 


\section{CONCLUSION}

Due to recency of many initiatives described above, complete and valid data is not available to describe the success of many of these ventures. Statistics indicate that increasing number of women are entering the IT workforce at various professional levels, that increased entrepreneurship initiatives in the form of cybercafe's as been on the rise, and that internet is now available in many rural areas. Suggestive of successful policy and grassroots level initiatives, these trends are encouraging since they represent a multi-faceted approach to a basic problem more prevalent in the underprivileged sections of the population - women and children. Many of the educational initiatives are encouraging since they promote IT education as a part of an overall improvement in the curriculum. However, the progress must be continuous and progressive and not just in response to market demands.

At a lower level, are the corporate and NGO initiatives with regard to computer technology as successful? Many of these programs are attempting to provide IT education to women from underprivileged backgrounds. Often these women have minimal or no education and are more socially constrained than those from more affluent environments. These constraints can reduce the potential of meaningful employment subsequent to a basic computer education. An example of such an initiative is the efforts of the SITA project described above. This project, though successful in training many women from low-income groups, did not result in meaningful employment for an estimated 70-trained women. The demoralizing outcome of this project resulted in its collapse in December 2000.

While these initiatives may enable underprivileged women to rise from their current vicious circle of poverty and lack of opportunities, they also run the risk of continuing to promote routine, low skill, and low paying IT initiatives for women while retaining the higher skilled jobs for men who already benefit from greater access to higher education and better training. As Hafkin and Taggert (2001) suggest, the provision of basic education and training for women must be improved in order for them to obtain the true benefit of globalization and IT growth. For this, policies that ensure IT education in early years and increased higher education for women must be effectively implemented before benefits of IT training can be achieved.

Obstacles faced by women in homes and work environments must be reduced for beneficial outcomes (Gurumurthy, 2004). New forms of these impediments, ironically often promoted through the use of ICTs, must also be recognized and eradicated in its nascency. For instance, a study by the International Labor Organization reports that 3 out of 4 call center workers face repeated sexual harassment over the phone (ILO, 2001). Similarly, promotion of pornography via internet is another looming threat to the equalization of female work conditions in many of these countries.

Results of many initiatives discussed above will be slow in emerging. A micro level improvement in women's education, social, and economic infrastructures must emerge in order for the true benefits of these initiatives to set in. This may take a few decades. However, the increased recognition of women in the workforce by the government, and a grassroots level effort by NGOs and corporations appears to be the right strategy for bringing rapid changes for female representation in IT. For researchers, India provides a unique opportunity to examine issues related to upliftment of women in a specific sector. In stark contrast to the gradual development of IT sector in most developed nations, India's rapidly expanding IT sector poses unique challenges and opportunities that are ripe for examination in research settings.

\section{REFERENCES}

Choudhary, T. H. (1999) India's evolution into an information society. The Journal of Policy, Regulation, and Strategy for Communications, 1(2), I71-176.

DDSI - Dependability Development Support Initiative (2002). National dependency policy environments-India. Retrieved February 25, 2005, from http://www.ddsi.org/Documents/final\%20docs/ DDSI_Country_Reports_Final_India.pdf

Gurumurthy, A. (2004) Bridge development-Gender and ICT. Institute of Development Studies. http://www.bridge.ids.ac.uk/reports/CEP-ICTsOR.pdf 
Hafkin, N., \& Taggert, N. (2001). Gender, information technology, and developing countries: An analytic study. Office of Women in Development Bureau for Global Programs, Field Support, and Research, United States Agency for International Development (USAID).

IBM. (2005). IBM technology camps inspire worldwide EXCITEment. Retrieved February 25, 2005, from http://www.ibm.com/ibm/ibmgives/grant/education/camp.shtml

International Labor Organization-ILO. (2001). The information technology revolution: Widening or bridging gender gaps? ILO department of Communication. Retrieved from http://www.ilo.org/public/ english/bureau/inf/pkits/wer2001/wer01ch4.htm

Kelly, G. (1987). Setting state policy on women's education in the third world: Perspectives from comparative research. Comparative Education, 23(1), 95-102.

Klein, E. (1987). The diffusion of consciousness in the United States and Western Europe. In M. Katzenstein \& C. Mueller (Eds), The women's movements of the United States and Western Europe (pp. 23-43). Philadelphia, Temple University Press.

NASSCOM - National Association of Software and Service Companies. (2003). Corporate Social Responsibility - Going beyond the buzzword. Retrieved February 25, 2005, from http:// www.nasscom.org/newsline/feb03/feature.asp

Sane, K. V. (2001). ICT and Gender Empowerment - SITA project. February 25, 2005, from http:/ /www.cityshelter.org/08_itc/ex/06_itc_ex.htm

Sneddon, J. (2004) Women in information technology. Retrieved February 25, 2005, from http:// www.knighthunter.com/Articles/WomenInIT.asp

UNESCO. (2004). From darkness to light: Reaching the un-reached children. Retrieved February 25, 2005, from http://www.unesco.org/education/ efa/EFA_2004/inde_celebration.doc.
UNESCO-Asia Pacific Gender Equity in Science and Technology (India Report). (2002). Retrieved February 25, 2005, from http://www.unesco.or.id/ apgest/countryreports/india.shtml

Zappala, G. (2000). Civil society and the nonprofit sector: The role of volunteers. Research and Advocacy Briefing Paper. Retrieved February 25,2005 , from http://www.smithfamily.com.au/ documents/Briefing_Paper_3.pdf

\section{KEY TERMS}

DOEACC: Department of Education Accreditation of Computer Courses, an autonomous division of the Indian Department of Information Technology tasked with the accreditation of computer courses-http://www.doeacc.org.in/

ERNET: Education and Research Network, a project initiated by Indian Ministry of Communications and Information Technology that has undertaken the establishment of a national network to support research and development in educational institutions—http://www.mit.gov.in/hrd/ernet.asp

MIT: The Ministry of Communication and Information Technology formed by the Indian government to oversee and direct the design, development, and management of technological education and progress in India - http://www.mit.gov.in/

NPEGEL: The National Program for the Education of Girls at the Elementary Level intended to improve the educational conditions of women and girls in India with special emphasis on technological training.

UGC: University Grants Commission, a government organization with two broad level functions, providing funds to Indian educational institutions and coordination, determination, and maintenance of standards in institutions of higher education-http:// www.ugc.ac.in/ 